$\begin{array}{r}\text { Volume and Issues Obtainable at Center for Sustainability Research and Consultancy } \\ \text { Journal of Accounting and Finance in Emerging Economies } \\ \text { ISSN: 2519-0318 ISSN (E) 2518-8488 } \\ \text { Volume 6: Issue 4 December 2020 } \\ \text { JSRC } \\ \text { Journal homepage: www.publishing.globalcsrc.org/jafee } \\ \hline\end{array}$

\title{
Drivers of Stock Market Growth in Pakistan: How Relevant is Irrelevant?
}

\author{
${ }^{1}$ Areeba Khan, ${ }^{2}$ Quratul Ain, ${ }^{3}$ Hafiz Abdur Rashid \\ ${ }^{1}$ The Islamia University of Bahawalpur Pakistan, areeba.khan@iub.edu.pk \\ ${ }^{2}$ The Islamia University of Bahawalpur Pakistan, qurat.ul.ain_mumtaz22@ @otmail.com \\ ${ }^{3}$ Assistant Professor, Hailey College of Commerce, University of the Punjab Pakistan, \\ ha.rashid.hcc@gmail.com
}

\begin{tabular}{l}
\hline ARTICLE DETAILS \\
\hline History \\
Revised format: November \\
2020 \\
Available Online: December \\
2020
\end{tabular}

Keywords

Stock Market Capitalization

to GDP ratio; Capacity

Building; Gross fixed asset

formation, Use of IMF credit,

Private credit to GDP

\section{JEL Classification}

M4, M40

\begin{abstract}
Purpose: Pakistan's stock market has experienced severe downside volatility after its classification in MSCI's emerging market index in 2016. Global pandemic, political instability and capital limitations through money laundering control mechanisms have exposed the foundations of capital allocation to an escalating risk of default. The situation prerequisites a review of contentious relationship between drivers of economic growth and stock market expansion. This paper seeks to examine the relationship between non-financial and banal drivers of economic growth and their relative impact on stock market development in Pakistan, building on the fact that financial market development is a direct outcome of economic growth and development of the generic capabilities of production and capital formation through profit trails. Design/Methodology/Approach: ARDL approach is used to analyze the contribution of capital formation and allocation through generic productivity and risk allocation mechanism. The paper discusses GDP growth, Gross fixed capital formation, Private credit and use of IMF credit as instrumental in determining stock market expansion. Implications/Originality/Value: Originality of the research transpires from the fact that key outputs of real sector have been added to analyze the development of financial market which have long been ignored as extraneous for empirical analysis.
\end{abstract}

(C) 2020 Center for Sustainability Research and Consultancy Pakistan under a Creative Commons Attribution-NonCommercial-ShareAlike 4.0

Corresponding author's email address: areeba.khan@iub.edu.pk

Recommended citation: Khan, A., Ain, Q. and Rashid, H. A. (2020). Drivers of Stock Market Growth in Pakistan: How Relevant is Irrelevant?. Journal of Accounting and Finance in Emerging Economies, 6 (4), 1189-1197

\section{Introduction}

Stock markets may be considered the economic pulse of a country. In the start of year 2019 it was expected that Pakistan, a developing country facing flagging growth, war on terror, regime change inspired political instability, and money laundering allegations, would be downgraded from Emerging Market Index of Morgan Stanley Capital International (MSCI) to the Frontier Market Index. The semi- 
annual index review committee found performance of the listed large and mid-cap stocks as uninspiring however, Pakistan was indorsed to retain its position in the Emerging Market Index till further review.

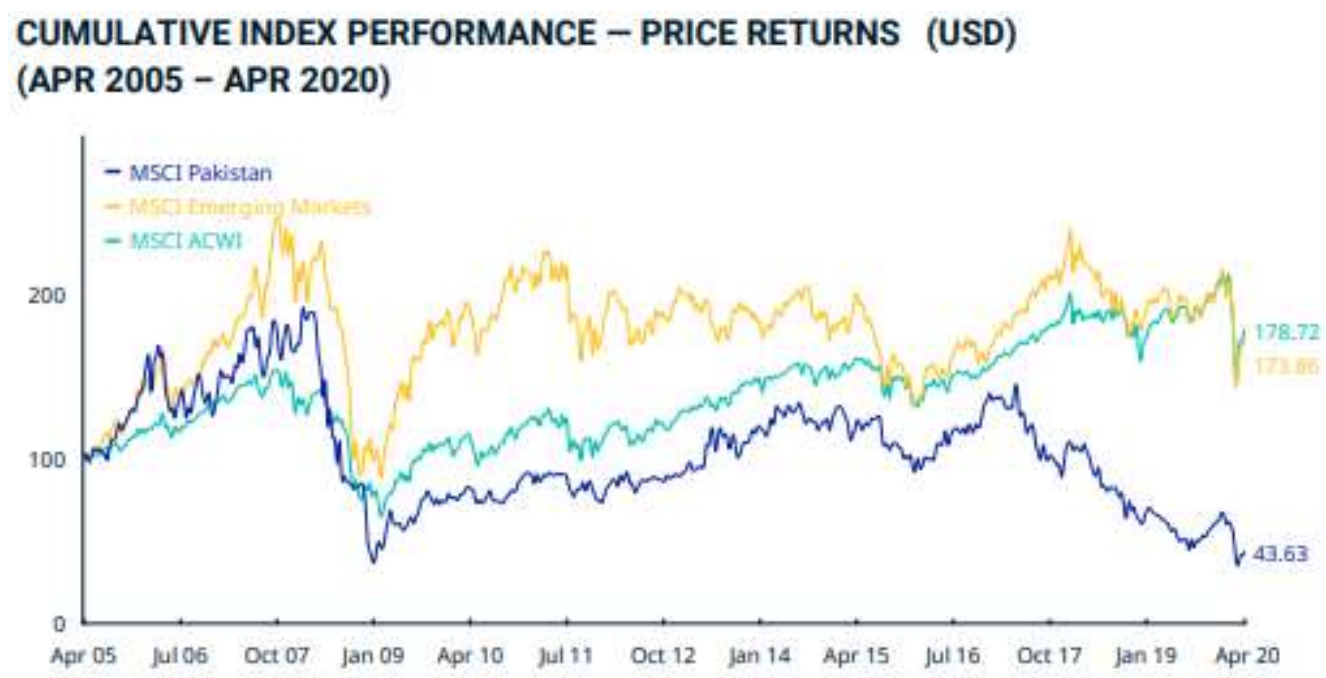

Figure 1.1 MSCI Comparative Index performance (Source: MSCI Pakistan, 2020)

The dismal market performance was attributed to high volatility and low free float market capitalization, falling short of the minimum standards for MSCI. This was contrary to the expectations of \$around \$500 million from a total of 1.5-\$1.7 trillion in passive portfolio investment influx, forecasted in 2017 (MSCI, 2019). With Covid-19 pandemic hitting in first quarter of 2020, the stock markets took a nosedive losing millions for individual and institutional investors. Dismal economic forecasts loom over a highly volatile stock market with steep decline in annualized returns. The scenario brings attention back to the question regarding nexus of financial markets and economic growth and causal inference acclimatizing the capacity building stipulations. Building capacity in the stock market (Mora \& Logan, 2010) will essentially require stabilization of macroeconomic indicators like currency flows, capital accounts FATF regulations, political stability, interest rates, inflation and others. Government expenditures (Rahman et al., 2017), allocation efficiency of capital inflows and physical capital formation generated by real sector (primary sector) contribution to the economy were generally ignored in studies concentrated on financial market growth and expansion, considering fiscal and financial issues different from real time growth recce (Wu et al., 2010). At present, Pakistan is facing the risk of default on debt servicing and other international payments due on Euro bonds and Ijara Sukuk. The economic growth and stock market development nexus gets more complicated under the conditions of default, extending the debate started $b$ Goldsmith (1969) contending the financial sector development as a function of demand and supply of funds. Demigurc Kunt \& Levine (1996) were the first to discuss the reverse causality of stock market development with economic growth with financial sector liberalization as a mediating variable. The capacity building of stock market may prompt economic recuperation that Pakistan is so desperately searching for. This paper seeks to identify the drivers of stock market development from real sector, adjusted for risk premium and capital allocation efficacy for economic growth and development. The paper is structured in four sections. First section deals with introduction and background, followed by the second section on stock market expansion literature and capacity building. The third section deals with empirical specification of variables of interest and the fourth section presents the discussion on results and findings.

\section{Stock market expansion and capacity building for economic development (Buffet ratio)}

The financial markets and growth linkage is theoretically verifiable if not empirically validated (Levine, 1997), however causality is contentious with advocates of theory of financial intermediation and financial deepening (Rousseau \& Watchel, 2000). The evidence supporting reverse causality between economic growth and financial markets has grown stronger in the last few years (Beck \& Levine, 2004), 
resonant of changing equations in developing economies and their relative degree of financial liberalization (Graff, 2003). Depth of financial markets is prevalently analyzed by the valuation measure profoundly known as the Warren Buffet ratio. The ratio was identified as the only sound measure of stock market growth and development by the American investor (Bayraktar, 2014). Stock market capitalization to Gross Domestic Product ratio (Buffet ratio) has been useful in cross country comparisons of financial market strength and development as well as capacity building measures (Barajas, Chami \& Yousefi, 2013).

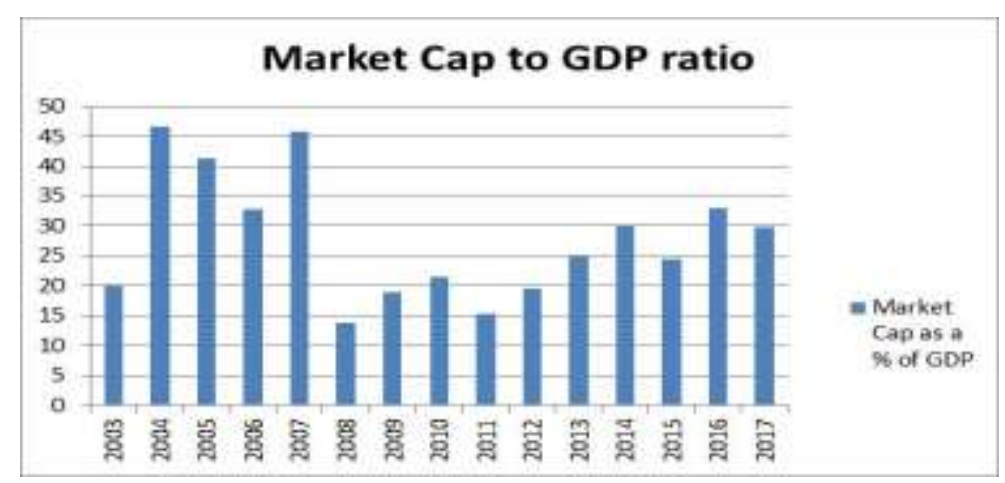

Figure 2.1 Trends in Stock market capitalization to GDP ratio

Economists and researchers in finance have long since debating the role of real sectors (primary) sectors in the economic development. The supply and demand theory of funds also postulate the same view where real sectors represented major demand of funds as well sources of supply through rent and profit extraction. The link towards equity generation from stock market is yet unexplored. King \& Levine (1993) identify stock market development and growth as a major factor in economic development of a country with services such as risk arbitrage, financial inclusion, liquidity provision and diversification. This cavalcade of research findings has periodically been fenced by financial, political and endemic crisis, to the extent to cause serious dubieties in vital correlations (Wang, 2010). The popularly impugned drivers for stock market growth and development as recced from studies in the area of economics and finance include Gross Domestic Product (GDP), described as value of total product and services output for the year. Theoretical and empirical studies have confirmed GDP growth rate as robust indicator of growth of financial markets (Levine, 2010). GDP is calculated at market price with its annual growth percentage. GDP is the sum of gross value added by all resident producers in the economy adjusted for taxes and subsidies. The growing importance of stock markets in the recent times made it imperative to thoroughly research the link between stock market development and GDP growth, discounting the impact of relevant macroeconomic factors like foreign exchange and inflation (Arestis, Demetriades \& Luintel, 2001). The bi-causal nature of relationship between stock market development and GDP growth was identified by Mukherjee \& Bose (2008), postulating that propounding liquidity provided by capital markets played a vital role in enhancing the propensity to save and invest. It is argued that capital allocation is the focal function of the stock markets which enables to channel excess from savers to the deficient sectors. Study of literature presents four perspectives on the stock market and growth relationship. The supply led growth theory suggests economic development is dependent on stock market growth (Levine, 2005). The demand led theory of economic growth suggests that economic development fosters stock market growth (Wang, 2010). The third perspective on stock market development and economic growth postulates that both have an interdependent relationship (Mukherjee $\&$ Bose, 2008). Finally, some studies are inconclusive on relationship between stock market growth and economic growth and development, citing it as an arbitrary correlation (Zegada, 2011). According to Arcand et al (2005) economies can either be classified as deep finance sector economies with a welldeveloped banking sector or market-based economies with a well-balanced stock market and liquidity plays the role of a catalyst in both (Levine, 1997).

\section{Model specification}


The drivers of stock market development and expansion recced from the past studies include GDP annual growth rate expressed as gross value of output of resident producers adjusted for taxes and subsidies. Leading economic sectors can also be helpful in determining the demand of funds (Wang, 2010). The supply theory of funds postulates that causal relationship is directed from interest rates and exchange rates to economic development. Alghamedi, (2012) identified Gross Fixed Assets as a proxy criterion for economic growth in a country, which may result in capital market expansion.
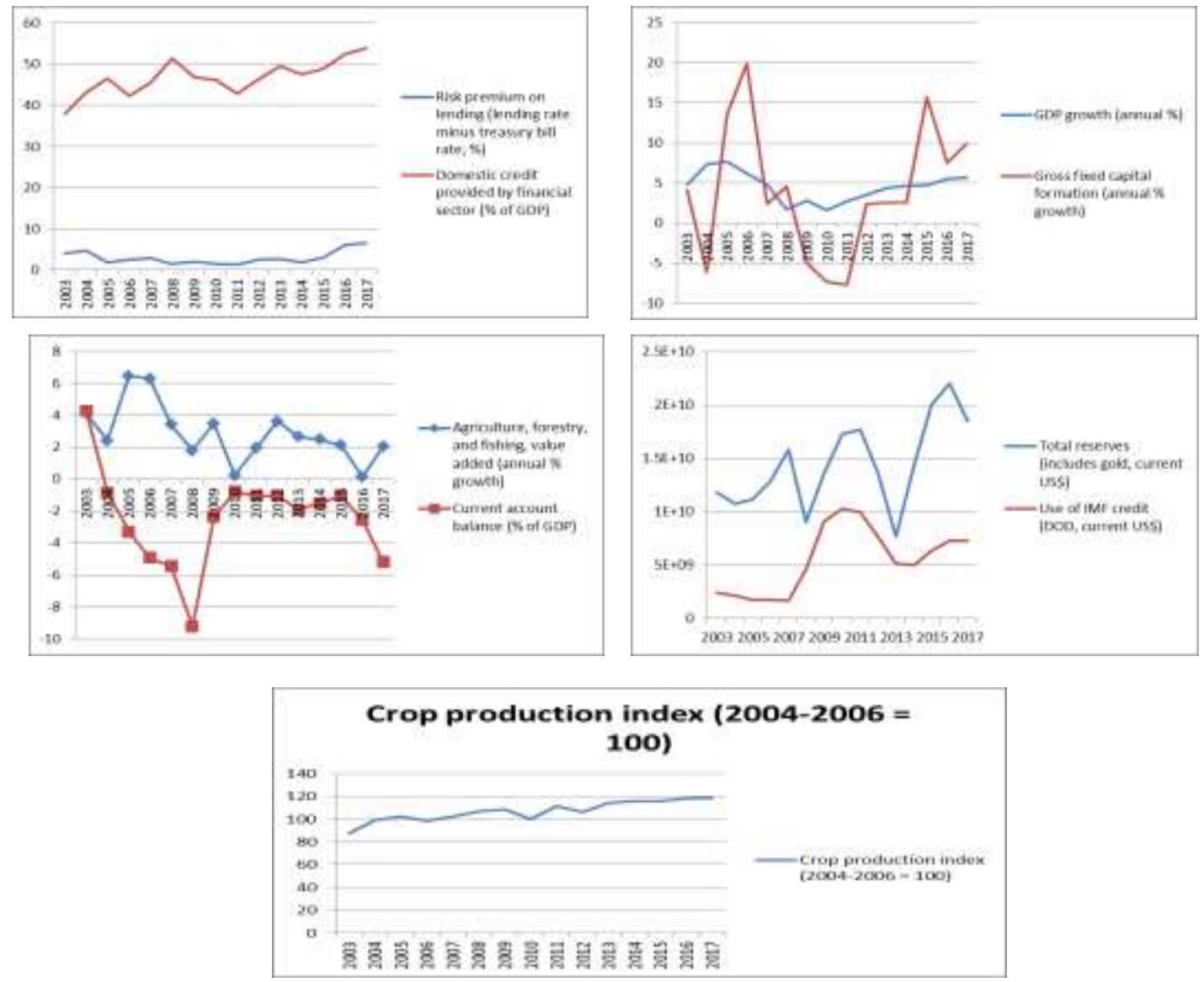

Figure 2.2 Time series analysis of Macroeconomic variables 

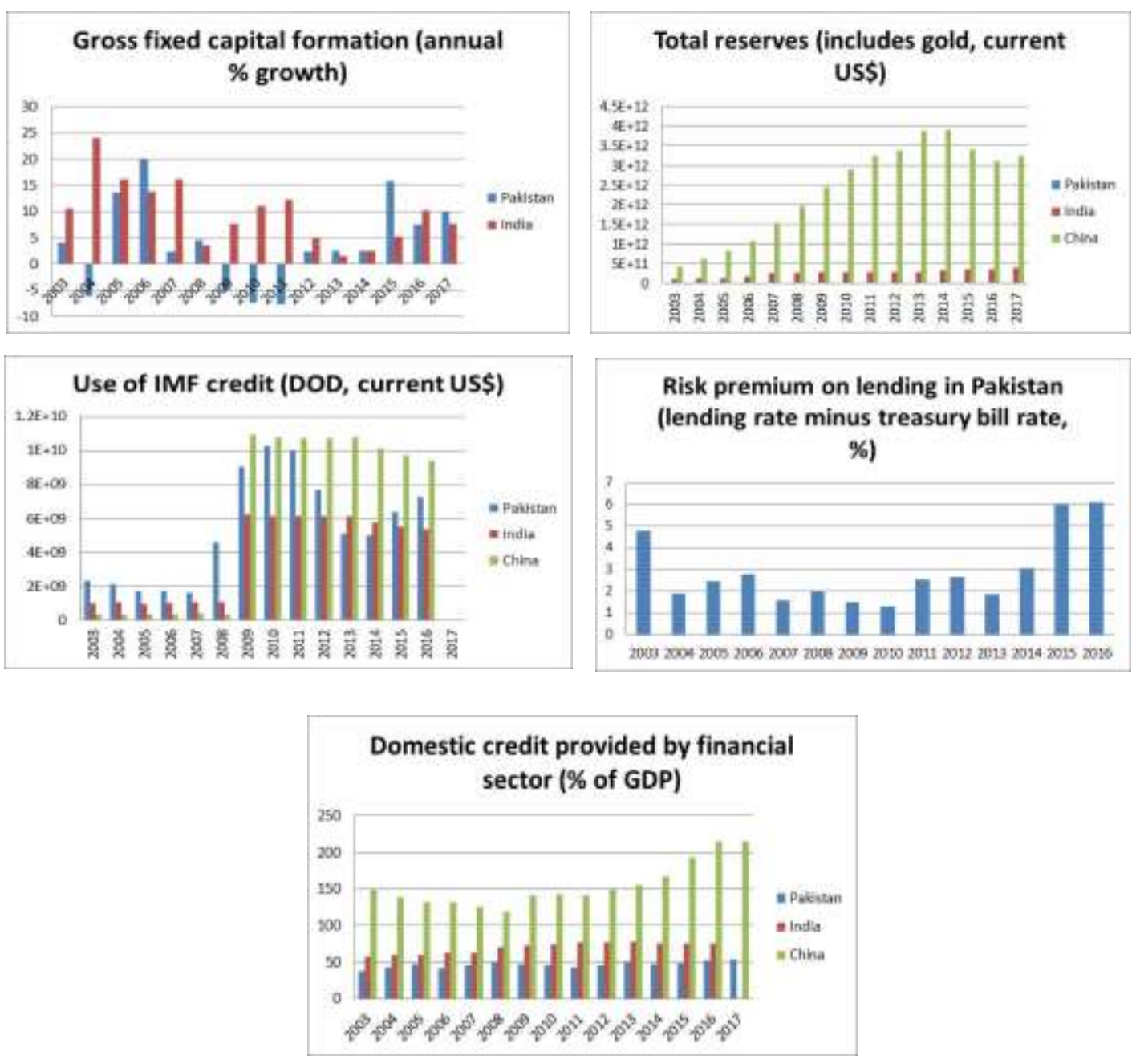

Figure2.3 Comparative analysis of Macroeconomic variables

The Global Financial Development Database (GFDD) uses risk premium on lending as a common measure for financial deepening of a country. Agriculture sector's growth on annual basis inclusive of forestry, fishing, hunting, cultivation premium on crops and livestock as means of sustenance of an agrarian economy (Wang, 2010). The origin of value added is determined by the International Standard Industrial Classification (ISIC). Crop production index represents not only the source of funds but potential future usage through financial inclusion. Average annual growth of gross fixed assets exhibits total capital formation in an economy and potential financial stability through the capital backup (Levine, 2005). Total reserves and use of IMF credit are factors that may bring downward pressures on a developing economy (Zegada, 2011). Compared to the other emerging economies classified in MSCI index, the macroeconomic variables for study perform worse over time in relation to market capitalization to GDP ratio (Buffet indicator). Gross Capital Formation has been declining in the past few years. The slide begun after the Global Financial Crisis, where many of the related economies were hit severely. Since 2009 and before, Pakistan has been dependent on international grants and IMF's structural adjustment programs. In such a situation with heavy debt servicing and massive international payments, maintaining the value of dollar and the amount of foreign exchange has always been challenging for the incumbent Governments. Market Cap to GDP or the Buffet indicator is a financial sector value measure for a market-based developing economy used by GFDD, described as follows:

Market Cap/GDP ratio $=($ Market Capitalization /GDP of an economy $* 100$

The actual growth of an economy may be dependent upon type and variety of financing available as may as well propel future growth by adding to the capacity of these investment channels. 


\section{Empirical results}

Data used were derived from Global Financial Development Database (DFDD) for the 15 years from 2003 to 2017. Normality tests were run on the data to determine normal distribution. This study makes use of Market Capitalization to GDP ratio $(M K T C A P)$ as the dependent variable and Agriculture \& Forestry $(A F)$, Crop Production Index $(C P R I)$, Current account balance $(C A B)$, Domestic Credit Provided $(D C P)$, GDP growth rate $(G R)$, Gross fixed capital formation $(G F C F)$, Risk premium $(R P L)$, Total reserves $(T L)$ and Use of IMF credit (UIC)as dependent variables. All variables were chosen for their theoretical and rhetoric relevance.

$M K T C A P=\alpha+\beta_{1} C P R I+\beta_{2} A F+\beta_{3} C A B+\beta_{4} D C P+\beta_{5} G R+\beta_{6} G F C M+\beta_{7} R P L+\beta_{8} T R+\beta_{9} \mathrm{UIC}+\varepsilon$

Ordinary Least Squares (OLS) was run on the data to establish causal relationship through regression. The adjusted $\mathrm{R}^{2}$ of 0.929 showed a good fit, thereby strong predictive capacity of the model. Regressing the independent variables further of Market Cap to GDP, two of the predictors, GFCF and UIC turn significant while adjusted $\mathrm{R}^{2}$ didn't show much change.
R-squared
0.98
Mean dependent var
27.87
Adjusted R-squared
0.93
S.D. dependent var
11.48
S.E. of regression
2.96
Durbin-Watson stat
2.73

The results show that Gross fixed asset formation and domestic credit provided were significant for stock market expansion at the percentage of $10 \%$ and $5 \%$ respectively.

Table 4.2 OLS Results

\begin{tabular}{|l|l|l|}
\hline Variable & Coefficient & Std. Error \\
\hline C & 21.59 & 36.92 \\
\hline$A F R I$ & $\begin{array}{l}-0.46 \\
(0.15)\end{array}$ & 0.20 \\
\hline$C A B$ & $\begin{array}{l}1.45 \\
(0.35)\end{array}$ & 1.29 \\
\hline$D C P$ & $\begin{array}{l}2.31 \\
(0.19)\end{array}$ & 1.14 \\
\hline$G R$ & $\begin{array}{l}1.42 \\
(0.18)\end{array}$ & 0.62 \\
\hline$G F C M$ & $\begin{array}{l}0.05 \\
(0.99)\end{array}$ & 2.25 \\
\hline$R P L$ & $\begin{array}{l}-0.69 \\
(0.07)\end{array}$ & 0.19 \\
\hline$T R$ & $\begin{array}{l}-0.79 \\
(0.66)\end{array}$ & 1.60 \\
\hline UIC & $\begin{array}{l}1.32 \mathrm{E}-09 \\
(0.07)\end{array}$ & $3.98 \mathrm{E}-10$ \\
\hline
\end{tabular}


Figure 4.10LS Fit.

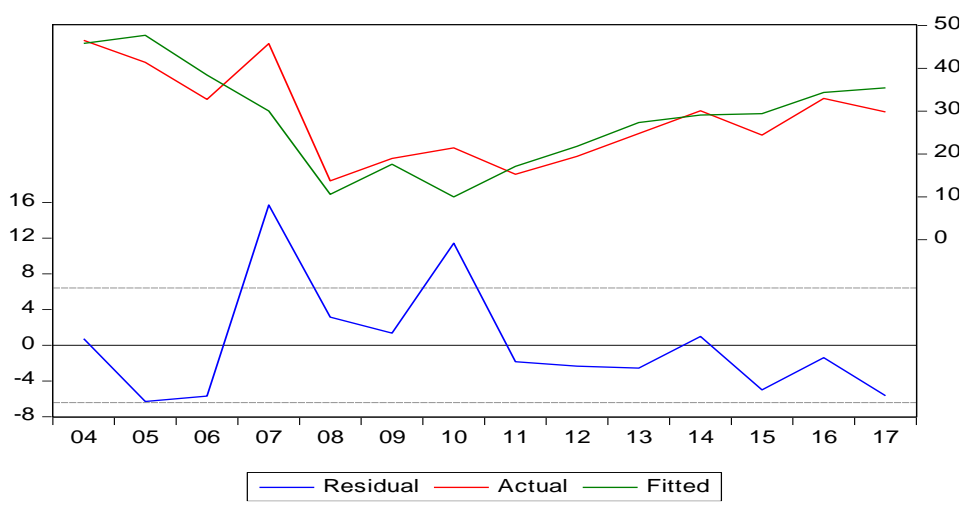

Pesaran, Shin \& Smith (2001) have supported Autoregressive distributed lag model (ARDL) as an appropriate technique to investigate the problem where lagged values of the variables are used as instruments to define and account for endogeneity relative to stock market movements.

Table 4.3 ARDL bound test for long term relationship

\begin{tabular}{|l|l|l|l|l|l|}
\hline Ho: No cointegration & Value & \multicolumn{2}{|l|}{$\mathbf{5 \%}$ Critical Bounds } & \multicolumn{2}{|l|}{ \% Critical Bounds } \\
\hline & & $\mathrm{I}(0)$ & $\mathrm{I}(1)$ & $\mathrm{I}(0)$ & $\mathrm{I}(1)$ \\
\hline Computed F-Statistic & 5.315 & 2.34 & 3.17 & 3.16 & 4.32 \\
\hline
\end{tabular}

\begin{tabular}{|l|l|l|l|c|}
\multicolumn{9}{c}{ Table 4.4 ARDL Estimation Results } \\
\hline \multicolumn{1}{|c|}{ Regressor } & \multicolumn{1}{c}{ Coefficient } & \multicolumn{1}{c|}{ Std. Error } & t-Statistic & Prob. \\
\hline$\triangle A F$ & 2.134 & 0.633 & 3.231 & 0.017 \\
\hline$\Delta C P R I$ & -0.468 & 0.200 & -2.330 & 0.058 \\
\hline$\Delta C A B$ & 1.662 & 0.534 & 3.111 & 0.020 \\
\hline$\Delta D C P$ & 1.624 & 0.469 & 3.457 & 0.013 \\
\hline$\Delta R P L$ & 1.403 & 1.140 & 1.230 & 0.264 \\
\hline$\Delta T R$ & $1.73 \mathrm{E}-09$ & $2.95 \mathrm{E}-10$ & 5.872 & 0.001 \\
\hline$\Delta \mathrm{UIC}$ & $-4.31 \mathrm{E}-09$ & $5.35 \mathrm{E}-10$ & -8.062 & 0.001 \\
\hline$\Delta G F C M$ & -0.704 & 0.140 & -5.014 & 0.002 \\
\hline Error Correction Term t-1 & -0.084 & \multicolumn{3}{|l}{} \\
\hline
\end{tabular}

Table 4.5 Diagnostic tests for ARDL

\begin{tabular}{|c|c|c|}
\hline \multicolumn{3}{|c|}{$\begin{array}{l}\text { Breusch-Godfrey Serial Correlation test } \\
\text { Null Hypothesis: No serial correlation }\end{array}$} \\
\hline F-Statistic & 0.813 & $(0.512)$ \\
\hline Obs. R sq. & 12.396 & $(0.212)$ \\
\hline \multicolumn{3}{|c|}{$\begin{array}{l}\text { Breusch-Pagan-Godfrey Heteroskedasticity test } \\
\text { Null Hypothesis: No Heteroskedasticity }\end{array}$} \\
\hline F-Statistic & 1.212 & $(0.181)$ \\
\hline Obs. R sq. & 40.510 & $(0.192)$ \\
\hline
\end{tabular}

\begin{tabular}{|c|c|c|r|r|c|}
\hline \multicolumn{7}{|c|}{ Table 4.6 Eigenvalues } \\
\hline & & & & Cumulative & Cumulative \\
\hline & & & Proportio & Value & Proportion \\
\hline Number & Value & Difference & $\boldsymbol{n}$ & 0.360 \\
\hline 1 & 3.247 & 1.204 & 0.360 & 3.247 & 0.587 \\
\hline 2 & 2.042 & 0.485 & 0.226 & 5.289 & 0.760 \\
\hline 3 & 1.556 & 0.634 & 0.172 & 6.845 & 0.863 \\
\hline 4 & 0.921 & 0.332 & 0.102 & 7.766 & 0.928 \\
\hline 5 & 0.588 & 0.275 & 0.065 & 8.355 & 0.963 \\
\hline 6 & 0.312 & 0.142 & 0.034 & 8.668 & 0.982 \\
\hline 7 & 0.170 & 0.017 & 0.019 & 8.839 & 0.999 \\
\hline 8 & 0.153 & 0.145 & 0.017 & 8.992 & 1.000 \\
\hline 9 & 0.007 & --- & 0.000 & 9.000 & \\
\hline
\end{tabular}


Table 4.3 and 4.4 show results of ARDL estimation with lagged variable values as regressors. The results show Crop production index, Domestic credit Gross fixed capital formulation, Total reserves and Use of IMF credit as significant factors in determining stock market capitalization to GDP ratio. In order to support the financial deepening initiative through stock market expansion, the Government needs to formulate policies to support economic growth for fixed asset formulation and make optimal use of the IMF credit.

\section{Conclusion}

The data analysis shows that real sectors of economy may generate and necessary impetus for stock market in Pakistan to grow and expand, moderated by the risk premiums and subsidized by use of IMF credit as well as reserves. Restructuring and reconditioning the bailout package with IMF may only work if the utilization is efficient and towards orthodox primary sectors with a greater yield. This study may be helpful in suggesting policy implication encompassing a focused strategy towards agriculture mechanization for higher yield crops, importance of agriculture subsidies and optimal utilization of the IMF credit. Govt. and private expenditure in Gross fixed asset formulation can be taken a crucial equity building exercise linking the financial markets with economic growth and the benefits thereof. The results of our study support recommendations for renewed and restructured Structural Adjustment Program (SAP) from IMF, and efficient allocation of the capital to increasing fixed asset formation and poverty alleviation.

\section{References}

Alajekwu, U. B and Achugbu, A. (2011). The Role of Stock Market Development on Economic Growth in Nigeria: A Time Series Analysis. African Research Review Vol. 5 (6), Serial No. 23, November.

Alghamed1, A., Misfer, A. (2012). Assessing the Impact of Stock Market Development on Economic Growth in Saudi Arabia: An Empirical Analysis. Durham theses, Durham University.

Antonios, A. (2010). Stock Market and Economic Growth: An Empirical Analysis for Germany. Business and Economics Journal, Volume 2010: BEJ-1.

Arestis, A. Demetriades, P. and Luintel, K. (2001). Financial Development and Economic Growth: The Role of Stock Markets. Journal of Money, Credit and Banking, Vol. 33 (1), pp 16 - 41.

Atje, R. and Jovanovic, B. (1993). Stocks markets and development. European Economic Review, 31, pp. 634-640.

Beck, T. and R. Levine (2004). Stock Markets, Banks and Growth: Panel Evidence. Journal of Banking and Finance, 28(3), pp. 423-42.

Boubakari, A. and Dehuan, J. (2010). The Role of Stock Market Development in Economic Growth: Evidence from Some Euronext Countries. International Journal of Financial Research Vol. 1, No. 1.

Boubtane, E. and Dramane C. (2011). Immigration, Growth and Unemployment: Panel Var Evidence from OECD Countries. Internet Address: http://www.univorleans.fr/leo/infer/COULIBALY.

Bouvatier, V., Antonia L-V., and Valérie M. (2012). Does The Banking Sector Structure Matter For Credit Procyclicality?. Economic Modelling, 29, pp. 1035-1044.

Caporale, G.M. and N. Spagnolo (2011). Stock Market Integration between three CEECs, Russia and the UK. Review of International Economics, 19(1), pp. 158-169.

Cheung, Y.W. and L.K. N. (1998). International Evidence on the Stock Market and Aggregate Economic Activity. Journal of Empirical Finance, 5, pp. 281-96.

Chizea, J. (2012). Stock Market Development and Economic Growth in Nigeria: A Time Series Study for the period 1980-2007. Doctoral thesis, Northumbria University.

Choi, I. (2001). Unit Root Tests for Panel Data. Journal of International Money and Finance, 20, p. 249-272.

Demirguc, K. A and Levine, R. (1996). Stock markets, corporate finance, and economic growth: an overview. World Bank Economic Review, 10(2), May, 223-239. 
Devereux, M. B. and G. W. Smith, (1994). International Risk Sharing and Economic Growth. International Economic Review, 35, pp. 535-50.

Diamond, D. W. (1996). Financial Intermediation as Delegated Monitoring: A Simple Example. Federal Reserve Bank of Richmond Economic Quarterly (82/3), pp. 51-66.

Enisan A. A. and Olufisayo A.O. (2009). Stock Market Development and Economic Growth: Evidence from Seven sub-Sahara African Countries. Journal of Economics and Business, 61, pp. 162-171.

Greenwood, J. and Smith, B. (1997). Financial Markets in Development and the Development of Financial Markets. Journal of Economic Dynamic and Control, 21, pp. 145-181.

Gurley, J. and E. Shaw (1955). Financial Aspects of Economic Development. American Economic Review, Vol. 45, pp. 515-537.

Harris, R. (1997). Stock Markets and Development: A Re-assessment. European Economic Review, 41, pp. 139-146.

Hartmann, P., Ferrando A., Fritzer F.H., Florian L.B and Marco L. D. (2006). The Performance of the European Financial System. European Central Bank, August.

Im, K. S., Pesaran, M. H., and Shin.Y. (2003). Testing for Unit Roots in Heterogeneous Panels. Journal of Econometrics, 115, pp. 53-74.

Levin, A., Chien-Fu and Chia-Shang C. (2002). Unit Root Tests in Panel Data: Asymptotic and FiniteSample Properties. Journal of Econometrics, 108, pp. 1-24.

Levine, R. (1991). Stock Markets, Growth, and the Tax Policy. Journal of Finance, 46, pp. 14451465.

Levine, R. and Zervos, S. (1998). Capital Control Liberalization and Stock Market Development. Vol.26, No.7, pp. 1169-1183.

Levine, R. (2005). Finance and Growth: Theory and Evidence. Handbook of Economic Growth, (Ed. Philippe Aghion and Steven N. Durlauf), pp. 865-93, Amsterdam.

Levine, R. and Sara Z. (1996); Stock Market Development and Long-run Growth. Policy Research Working Paper Series 1852, The World Bank.

Love, I. and Lea Z. (2006). Financial Development and Dynamic Investment Behavior; Evidence from Panel VAR. The Quarterly Journal Review of Economics and Finance, 46, pp. 190-210.

Lütkepohl, H. (2005). New Introduction to Multiple Time Series Analysis. International Journal of Economical Studies, 2015, Year:1, Vol:1, Issue:1

Maddala, G. S. and Wu, S. (1999). A Comparative Study of Unit Root Tests with Panel Data and A New Simple Test. Oxford Bulletin of Economics and Statistics, 61, pp. 631-52.

Mora, N. and A. Logan (2010). Shocks to Bank Capital: Evidence from UK Banks at Home and away. The Bank of England Working Paper Series, Working Paper No. 387.

Mukherjee, P. \& Bose, S. (2008) Does the Stock Market in India Move with Asia?: A Multivariate Cointegration-Vector Autoregression Approach. Emerging Markets Finance and Trade, 44:5, 522

Pesaran, M. H., Shin, Y., \& Smith, R. J. (2001). Bounds testing approaches to the analysis of level relationships. Journal of Applied Econometrics, 16,289-326

Rahman, M.M. (2017). Do population density, economic growth, energy use and exports adversely affect environmental quality in Asian populous countries? Renewable and Sustainable Energy Reviews, Vol. 77, pp. 506-514, available at: https://doi.org/10.1016/j.rser.2017.04.041

Rousseau, P.L. and Wachtel, P. (2000). Equity Markets and Growth: Cross-country Evidence on Timing and Outcomes. Journal of Banking and Finance, 24, pp. 1933-1957.

Smith, A. (1937). An Inquiry into the Nature and Causes of the Wealth of Nations. New York: Random House.

Wang, X. (2010). The Relationship Between Stock Market Volatility an Macroeconomic Volatility: Evidence from China. International Research Journal of Finance and Economics, Issue 49, pp. 149-160.

Wu, S.Y., Tang, J.H. and Lin, E.S. (2010). The impact of Government expenditure on economic growth: how sensitive to the level of development? Journal of Policy Modeling,Vol.32No.6,pp.804-817. 